\title{
Petrus Zitzscher (1652-97), en præst fra baroktiden
}

\author{
Af Asger Nyholm.
}

Om præsten Petrus Zitzscher udkom der efter hans d $\varnothing \mathrm{d}$ et mindeskrift, trykt i København.

Det var skik i det 16. og 17. århundrede, at højtstående personer ved deres død blev mindet $i$ ligtaler og sørgedigte. Det var de litterære sidestykker til tidens gravmonumenter og epitafier. Som disse efterhånden udviklede sig $i$ en stadig mere prangende og snørklet stil, således svulmede ligtalerne op til rene kunstpræstationer af lærdom og ordbram. Begravelserne blev til langtrukne ceremoniudfoldelser. * Vi begriber ikke den nervestyrke, som formåede at holde ud til al den pomp samt den tilhørende taleflom ved en datidig ligfærd", skriver en kender af tiden.

Mindeskriftet over Zitzscher — „Ehren-Pyramide«, som det kaldes - indeholder, som det var sædvane, dels en mindetale over den afdøde, dels nogle, mest latinske, s $\varnothing$ rgedigte ( Epicedia «). Blandt forfatterne til sørgedigtene mærker man sig her præsten i Højst, Nic. Ewald, digterens bedstefader, og rektoren i Tønder, Christopher Bluhme, hofpræst Bluhmes fader. Digtene er i al deres højstemte lovprisning af den afdøde og med deres kunstige anvendelse af mytologiske og historiske billeder lidet oplysende. Om eet er de dog enige: de fremhæver alle Zitzschers store veltalenhed, som efter en af forfatternes mening stiller ham på linie med Sofokles eller Perikles. ,Vix talem Svadam secla futura dabunt $\kappa$, hedder det, eller:

Wer Zitzscher loben will / und Zitzschers hohe Gaben /

Muss Zitzschers Mund und Zitzschers Zunge haben.

Selve mindetalen er forfattet af Bartholomæus Christianus Egidius. Dette navn er en latiniseret form af det jævne s $\emptyset$ nderjyske navn: Bertel Christian Gjødesen (1673-1733). Egidius var senere præst i Varnæs og udgav den såkaldte Varnæs-Salmebog, der var en dansk omplantning af delvis pietistisk tysk salmedigtning. Mindetalen oplyser, som disse ligprædikener sædvanlig gør det, mere om sin forfatters lærdom og veltalenhed end om den afdødes liv. Man må skrælle meget bort, før man finder ind til de magre oplysninger om den afdødes liv. 
En anden vigtig kilde til oplysning af Zitzschers liv er den lærde Flensborg-rektor, Johannes Mollers (1661-1725) store samlerrærk: Cimbria Litterata (udgivet efter forfatterens død 1744), der er en sand fundgrube til hertugdømmernes personalhistorie.

Af Zitzscher selv er der efterladt nogle få ligprædikener. Der har eksisteret flere, men de er, ligesom en samling pradikener, ikke til at skaffe tilveje mere.

Kilder:

Ehren-Pyramide Dem Weiland .... Petro Zitzschero. Von Bartholo Christiano Egidii. Copenhagen, Anno 1700.

Johannes Moller: Cimbria Litterata, 1744, II, s. 1038.

C. E. Carstens i Schlesw.-Holst.-Lauenb. Kirchen- und Schulblatt 27/3 1886, nr. 13.

Af Zitzscher findes opbevaret:

Henochs Wall- und Himmelfahrt in Leben und Sterben des ... Herrn M. Hermanni Erdtmanns ... Glückstadt, 1688. E. døde som biskop i Holsten 1687. Han var i årene 1678-84 hofpræest hos enkedronningen i Kbh.

Die gekrönte Priester-Treue bey ... H. Hn. Justi Valentini Steemann ... Glückstadt, 1689. St. døde som Erdmanns efterfølger i bispeembedet. Han havde fra 1655 til 1688 været tysk præst i Helsingor.

Die rühmliche und seelige Beständigkeit Eines redlichen Christen. Bey Christlicher Beerdigung des Weyland .... Herrn Friederich Jürgensen. (Uden årstal). Fr. Jørg. døde 1694 som amtsskriver i Tønder.

Følgende skrifter af Zitzscher har forgæves været eftersøgt:

Leichen-Rede über Marqv. Guden. Glückstadt 1690.

Leichen-Rede über Reim. Struven. Glückstadt 1694.

Conciones miscellaneæ. Glückstadt 1696 .

Peter Zitzscher er født 1652, fire år efter Christian 4.'s død. Hans barndom faldt i Karl-Gustav-krigenes år, da fremmede tropper hargende drog gennem landet, og da besiddelserne øst for Øresund gik tabt. Han har som dreng oplevet trængselsdagene under Københavns belejring, da kongen og dronningen ved deres optræden vandt det københavnske borgerskabs hengivenhed, og han har oplevet de bevægede dage under rigsdagen i København, hvis højdepunkt blev den pompose pragtudfoldelse, da kong Frederik 3. den 18. oktober 1660 på slotspladsen i København blev hyldet som landets arveherre.

Ud af Egidius' overstrømmende lovord kan man ikke danne 


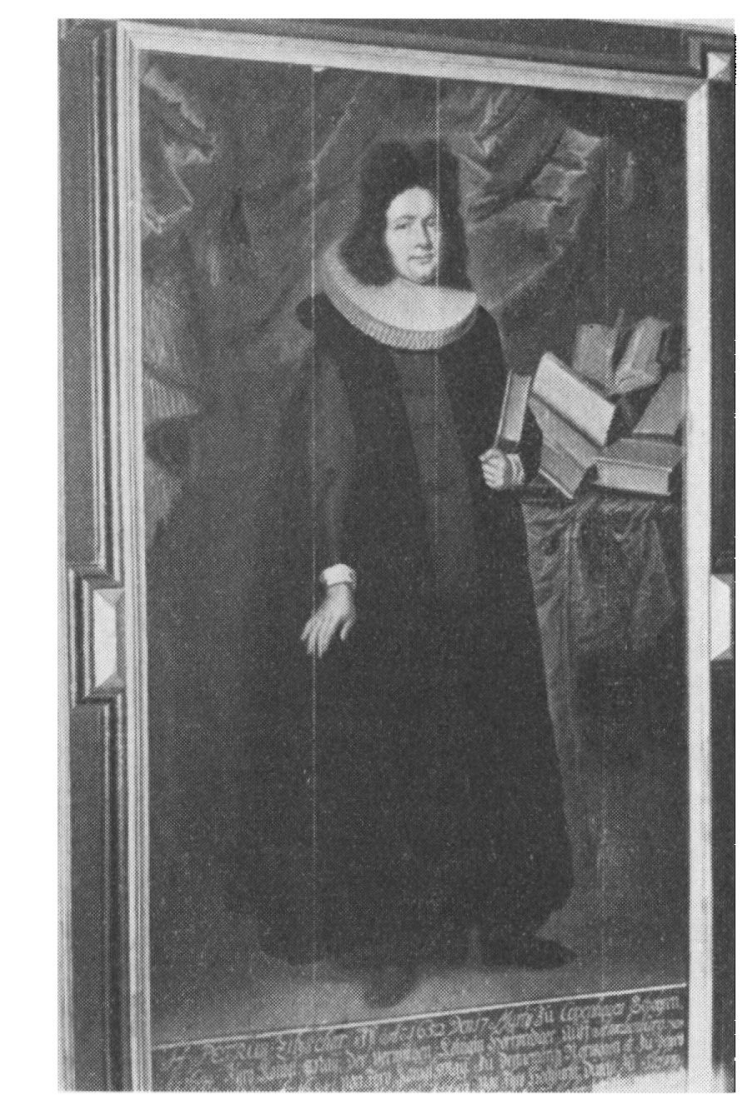

Petrus Zitzscher. Maleri i kirkemuseet, Tonder. (Fot. Gabs).

sig noget billede af Zitzschers forældre. Faderen, Ulrich Zitzscher, var kongelig Majestæts »wohlbestalter Herold «, og moderen hed Saara Zitzscher. Det hørte til heroldens bestilling at være inde $i$ heraldikken og den dermed sammenhængende rangf $\emptyset$ lge og ceremoniordning. I en tid, da den honneite ambition spillede en så stor rolle, må faderens bestilling derfor have været af en vis betydning ved hoffet, hvor der trods rigets betrængte finanser udfoldedes en udfordrende pragt med den magt- og pragtsyge dronning Sophie Amalie som midtpunkt, hvad enten hun brille- 
rede på svanejagter eller agerede $\mathbf{i}$ hyrdespil og balletter efter fransk mode.

Dronningen fik sit $\phi$ nske opfyldt, at se magten i riget blive frataget adelen og overdraget til kongen. Men hun glemte ikke de år, der var gået forud. Da hun 15 år gammel var blevet gift med Christian 4.'s næstældste søn, hertug Frederik, der da var fyrstbiskop af Bremen, var der ingen udsigt til, at hun skulde blive Danmarks dronning. I de følgende år blev xgteparrets stilling endda forværret. Ved Torstensonkrigen led Danmark nederlag, og hertug Frederik mistede Bremen. Figteparret måtte tage ophold i Flensborg, og Christian 4. gav dem kun modvillig den pengehjælp, de beh $\varnothing$ vede. Da hertug Frederik på grund af den ældre broders død opnåede kongemagten i Danmark efter faderen, måtte han underskrive en håndfæstning, der blev den hårdeste, nogen dansk konge endnu havde underskrevet. Det glemte Sophie Amalie aldrig den danske adel. Heller ikke glemte hun de mange tilsidesættelser, hun gang på gang havde f $\not l t$ sig udsat for af Christian 4.'s stolte datter, Leonora Christine. Hun søgte derfor sin omgangskreds blandt mennesker, der stod det tidligere danske hof og den gamle danske adel fjernt, ofte folk af tysk herkomst.

Hofherolden har vel været blandt dem, hun folte sig tryg ved, siden hun viste hans søn så stor bevågenhed.

Moller beretter, at dronningen tog sig af hans opdragelse fra hans 5. til hans 33. år, og på hendes bekostning blev han sendt til skoler, universiteter og fremmede lande. Egidius skriver, at han ved ikke, om Zitzscher skylder sin egen moder, fra hvem han havde livet, mere, end han skylder den højsalige dronning, fra hvem han havde et liv in estime «. Med sirlig hentydning til dronningens navn skriver han i tidens stil, at hun har været ham en ret Sophia Amalia: en Amalia, thi hun elskede ham, en Sophia, thi hun lod ham opdrage til visdom.

Traditionen beretter, at Zitzscher $i$ sine f $\varnothing$ rste år blev oplært af de samme lærere som hendes søn, den senere Christian 5., at - som Egidius skriver - den ringe Zitzscher har stået ved den afdøde stormægtigste monark Christian 5.'s side og 
sammen med ham, som også med de andre kongelige prinser, indsamlet den frugtbærende læres f $\varnothing$ rste frugter.

Nu var Zitzscher 6 år yngre end kronprinsen, hvorimod han var 1 år ældre end dennes broder, prins Jørgen, der var dronningens foretrukne barn. Det er derfor mindre sandsynligt, at Zitzscher er blevet opdraget af kronprinsens lærere, blandt hvilke man træffer matematikeren Villum Lange og Frederik 3.'s livlæge Poul Moth, hvis datter siden blev Christian 5.'s elskerinde. Derimod kan man bedre tænke sig, at han er opdraget af prins Jørgens lærere, hannoveraneren Otto Grote og den soranske professor i historie, Christen Lodberg, der som belønning for sin opdragelse af prinsen fik domprovstiet i Roskilde og siden blev biskop i Ribe.

Siden blev Zitzscher sat i Horsens latinskole. Efter reformationens indf $\phi$ relse var det ved lov fastsat, at der i hver k $\phi b s t a d$ skulde være en latinskole. Man skal ikke tænke sig for meget ved dette ord. Per Degn var gammel latinskoleelev. Tilmed var der forskel på skolerne. Kun de gamle katedralskoler måtte dimittere til universitetet. De andre skoler var af lavere rang, og de behøvede kun en mand med den laveste akademiske grad, en baccalaureus, til rektor. En sådan skole var Horsens latinskole. Dog havde de fleste af rektorerne i Horsens den højere magistergrad. Foruden skolens rektor var der to hørere, så skolen havde $i$ alt tre klasser, lectier. Kristendom og latin var selvfølgelig, som overalt dengang, hovedfagene.

Såre fattigt har det hele sikkert været. Skolens standard ses af en lidt senere indberetning fra Zitzschers rektor, Knud Olufsen, hvori det hedder, at der er 39 disciple, af hvilke de fleeste ere fattige B $\phi r n$. At Freqventzen er icke st $\phi r r e$, volder, at folckene her i Byen, som B $\phi$ rn hafve, ingen synderlig Lyst hafve at holde deres B $\phi$ rn til latinske Schole«.

Et yderst demoraliserende forhold var degnetjenesten, der bestod $i$, at eleverne gjorde tjeneste $i$ omegnens kirker om s $\varnothing n-$ dagen som degne (løbedegne). I 1654 har den daværende rektor herom givet en oplysende indberetning, hvori han skriver, at tjenesten i landsognene sætter b $\phi$ rnene ikke så lidt tilbage, og den lokker sikkert mange drenge, som man ellers kunde sætte 
et glimrende håb til, således gradvist bort fra deres pligt og fordærver dem således ved den lejlighed, der ved bryllupperne bydes dem til at skeje ud, at de helt fatter afsky for muserne. ${ }^{1)}$

Man vil naturligt spørge, hvorfor Zitzscher blev sendt til Horsens skole. Svaret synes nærliggende. Sjællands biskop, Hans Svane, stod hoffet nær. Han havde sin andel $i$, at kongedømmet blev arveligt. Hans Svane var født i Horsens. Han havde gået $i$ Horsens latinskole til sit 14. år (1620). 1655 skænkede han et legat til skolen. Svanes s $\emptyset$ sters $\emptyset$ n havde hen imod århundredets midte været rektor ved skolen. Han hed Laurits Ernstsen von Baden. Han blev siden kaldet til præst i Stouby og Hornum menigheder af Henrik Rantzau til Rosenvold.") Denne Henr. Rantzau var en af kongehusets st $\varnothing t t e r$, en mand, der ved sine kundskaber naturligt faldt $i$ den lærde konges smag og ledsagede ham på en rejse i Norge 1656, medens hans hustru blev i København som dronningens selskabsdame. Det er således ikke svært at se tilknytningen mellem Horsens skole og det milieu, der omgav dronningen. Hvem ved, on Zitzscher ikke har læst på Hans Svanes legat!

Zitzscher har åbenbart læst med godt udbytte under magister Olufsen. Ca. 15 år gammel må han være kommet til universitetet i Kobenhavn. Han havde - skriver Egidius - i den grad perfectioneret sig, at han efter få år blev befundet »capable» til at lade sig indpode $i$ »die florissante Academie zu Copenhagen «.

Man begyndte $i$ en ung alder på universitetet dengang. Reglementet var da også derefter. De unge studerende var under et nærgående opsyn, både med hensyn til undervisning og med hensyn til kirkegang, ja under måltiderne og på værelserne. Undervisningen lå $i$ den første studietid direkte $i$ forlængelse af skolegangen. Siden fulgte for de allerflestes vedkommende det teologiske studium, hvis væsentligste indhold var skriftlæsning på grundsprogene og dogmatik. Undervisningen foregik dels ved forelæsninger, der $\mathrm{i}$ regelen dikteredes, og dels ved de daglige

1) C. F. W. Bendz: Bidrag til Horsens lærde Skoles Historie, 1848, s. 51,52 .

2) Bendz, s. $49,25$. 
disputere $\varnothing v e l s e r$, der blev drevet i forbindelse med måltiderne i kommunitetssalen.

Teologien havde ved det tidspunkt et vist politisk indhold. Kirken havde under Hans Svanes f $\varnothing$ rerskab st $\varnothing$ ttet og godkendt enevaldens indf $\emptyset$ relse. Og medens $P$. Schumacher fuldførte kongeloven, det nye styres grundlov, skrev den teologiske professor Hans Vandal i årene efter 1663 sit store vark på 1000 sider om majestatsretten.

Han så $i$ den rene evangelisk-lutherske lare det sikreste fundament for kongedømmet og hævdede, at »en kristen konge må ikke tåle nogen i sine lande, der ikke holder ved den rette lære«. Han afviste et forslag om at give alle konfessioner fri religionsud $\emptyset$ velse i landet med den motivering, at katolikkerne sætter pavemagten over kongemagten, og de reformerte sætter folkets suverænitet over kongens suverænitet. Kun den lutherske lære anerkender kongens enevældige magt fuldtud.

Det gik så vidt med universitetets ensretning, at en professor, Chr. Nold, blev suspenderet fra sit embede ved universitetet, fordi man mistænkte ham for at tvivle om kongemagtens guddommelige oprindelse. Det er da let at forestille sig den atmosfare, som Zitzscher har levet i som meget ung student ved Københavns universitet.

Siden studerede Zitzscher - stadig på Sophie Amalies bekostning - ved forskellige universiteter i udlandet.

Han bes $\phi$ gte Tyskland, der endnu led under følgerne af trediveårskrigens $\varnothing$ delæggende kamp mellem katolikker og protestanter. Forholdet mellem de to trosretninger blev ivrigt drøftet. Nogle teologer mente, at parterne ved gensidig imødekommenhed burde finde et fælles grundlag at mødes pả. Andre teologer fandt, at deres kirkeafdelings særegne meninger var dem så dyrebare, at de måtte stille sig afvisende overfor alle afvigende læresætninger.

En førende skikkelse blandt dem, der $\emptyset$ nskede en udsoning, var en sønderjyde, præstes $\phi$ nnen Georg Calixtus (Jørgen Callesen) fra Medelby. Han var professor i Helmstedt i Braunschweig (1614-56). Han mente, at alle parter måtte kunne finde et fælles grundlag for troen i de læresætninger, som kirken havde 
udformet $i$ de første 5 århundreder efter Kristus. På dette grundlag måtte der kunne skabes en udsoning, så man i fremtiden kunne undgå en gentagelse af den blodige religionskamp, der havde vakt så mange gode menneskers afsky.

Calixtus's hårdeste modstander var Abraham Calov, der var professor i Wittenberg. Han var en af den lutherske rettroenheds mest hårdnakkede forkæmpere. Fast overbevist om, at hvert bogstav $i$ den hellige skrift var inspireret af helligånden, byggede han i et 12 binds værk på skriftens grundlag den lutherske dogmatik op med stejl polemisk front mod alle afvigende meninger.

Zitzscher lærte på sine rejser begge retninger at kende. Han bes $\varnothing$ gte f $\varnothing r s t$ universitetet i Helmstedt, altså i Sophie Amalies hjemland. I overstrømmende ord, hvormed han samtidig opnår at lægge sin bibelske lærdom for dagen, skildrer Ægidius Helmstedts betydning for Zitzscher: Det var et Gosen (1. Mosb. 47,4), hvor han kunde vandre $i$ våren og plukke de frie kunsters vellugtende lillier, et Elim (2. Mosb. 15, 27), hvor alle fakulteternes dybe kilder strømmede rigeligt, et Gibeon (Josv. 10, 12), hvor de som solen skinnende lærdomslys strålede for ham med en ny glans fra videnskaberne.

Egidius nævner to lærere, hos hvem Zitzscher både fik kost og opdragelse. Det var Gerhard T. Titius, der var professor i teologi og elev af Calixtus, og Christoph Schrader, en meget afholdt universitetslærer, der havde boet hos Calixtus og var hans mest begejstrede og dygtige elev. Han var professor i veltalenhed, hans indstilling var udpræget humanistisk, og han havde afslået at rykke ind $i$ det teologiske fakultet, måske for at holde sig udenfor de bitre teologiske stridigheder i tiden.

Således har Zitzscher i Helmstedt oplevet traditionerne fra Calixtus's dage. Til gengæld bes $\varnothing$ gte han siden universiteter med den modsatte indstilling. Han studerede i Wittenberg, hvor han kan have hørt selveste Abraham Calov. Han bes $\emptyset$ gte Leipzig, hvis teologer havde givet Calov deres tilslutning på modet i Thorn. Endelig var han i Jena, hvor man også afviste Calixtus, men dog ikke havde villet underskrive Calovs fordømmelse af ham.

I $\varnothing v$ rigt beretter Agidius, at Zitzscher var i Bøhmen og i 
Wien, i Regensburg, Ingolstadt og Augsburg, at han besøgte de betydeligste hoffer, de fornemste byer og både katolske, reformerte og lutherske universiteter i Tyskland. På baggrund af den strenge ensretning ved Københavns universitet overraskes man egentlig over at se, hvor frit man lod Zitzscher høste lærdom ved afvigende trossamfunds universiteter.

Så blev han af Sophie Amalie kaldt hjem og indsat som vicerektor i Nyk $\emptyset$ bing på Falster, »for at han som Joseph kunde udstr $\varnothing$ sin indsamlede lærdomssæd for andre«. Når han blev ansat i Nyk $\varnothing-$ bing, var det, fordi Sophie Amalie efter Frederik 3.'s død opholdt sig meget på Nykøbing slot, idet krongodset på LollandFalster var udlagt til hendes underhold. Med skolen havde hun nær berøring, da der fra slottet årlig udbetaltes et stipendium til disciplene, der til gengæld skulle synge ved gudstjenesterne på slottet.s)

Rektor ved skolen, indsat samme dag som Zitzscher, var hans gamle studiekammerat fra K $\phi$ benhavn, magister Simon Petersen Aarhus (f. 1644). Han havde som kandidat været huslærer i nogle år og havde siden holdt både disputatser og forelæsninger red universitetet, indtil han tog magistergraden og, anbefalet til Sophie Amalie, blev rektor i Nyk $\phi$ bing. Han har karakteriseret Zitzscher som »et godt og meget bekvem Subjectus $\ll{ }^{4}$ )

Zitzscher slukkede snart sit Kornhus«. Han var kun et år i Nykøbing. Så rejste han igen udenlands.

Han var i Hamborg, Leyden og Utrecht. Han bes $\phi$ gte England, hvor han må have oplevet Stuarternes kamp for enevælden, og hvor han $i$ et par år opholdt sig $i$ det konservative Oxford. Videre var han i Ludvig 14.'s Frankrig, hvor han så »Enevælden af Guds Naade $i$ renkultur. Flittigt og uden at skåne sit helbred skal Zitzscher have arbejdet under alle sine rejser, hvor han altid havde sine bøger med sig, ligesom Alexander altid havde Homers Iliade med sig - som Egidius udtrykker sig med en af de mange lærde lignelser, som han behager sig i.

3) M. Wittrup: Bidrag til Nykjøbing Kathedralskoles Historie, 1866, s. 31.

4) Immanuel Barfod: Den falsterske Gejstligheds Personalhistorie, I, 1851 , s. 42,95 . 
Da Zitzscher kom tilbage, blev han 1682 ekstraordinær og $\mathrm{i}$ 1684 virkelig hofpræst på Amalienborg hos Sophie Amalie. I 2 år holdt han »onsdagsprædikenerne « for enkedronningen. De gjorde »als Nett-præparirte Raketten « så stærkt indtryk på hende, at hun ikke ville lade ham rejse med til England som prins Jørgens hofpræst.

Den omtalte prins J $\emptyset$ rgen, Frederik 3.'s næstældste $s \emptyset n$, stod Sophie Amalies hjerte mere nær end Christian 5., og hun havde hellere set ham på tronen. En tid var der tale om, at prins I $\phi r g e n$ skulle være konge af Polen, men det blev dog ikke til noget, bl. a. fordi han ikke ville gå over til katolicismen. Prins Jørgen blev så i 1683 gift med prinsesse Anna, den senere kong Jacob 2.'s datter. Hun blev siden dronning i England. Det vidner om Zitzschers anseelse, at det har været på tale at sende ham til England som hofpræst for prins Jørgen.

Med mange og omstæendelige betragtninger over ægteskabets opståen og lykke oplyser Ægidius, at Zitzscher blev gift med en datter af en godsinspekt $\not r$, Simon Walter, fra Hellerup på Fyn. Hendes broder var kapellan i Stubbek $\varnothing$ bing. ${ }^{5}$ )

1685 d $\emptyset$ de Sophie Amalie. På Christian 5.'s befaling blev Zitzscher udnævnt til hofpræst i Glückstadt. Bet $\varnothing d$ det en forvisning fra København? Christian 5 . havde ofte varet irriteret over sin strenge og magtglade moders formanende udbrud, når hun ikke var tilfreds med kongens bestemmelser: „Was hör' ich nun? «. Han havde ofte følt sig tilsidesat til fordel for prins Jørgen, sidst endog $\mathrm{i}$ hendes efterladte testamente.") Det kan derfor meget vel tænkes, at det har været ham tilpas at få hendes hofpræst, som hun selv havde protegeret frem, fjernet fra hoffet. Det kunne endda se ud, som om Ægidius på sin kunstfærdige måde søger at imødegå rygter i den retning, idet han skriver, at København blev aldrig et Gibea (Dom. 14, 14), hvor solen gik ned for Zitzscher, d. v. s. hvor den store nordiske sol, Christian 5., unddrog ham sine nådestråler. Som Belsazar fandt Daniel værdig til en purpurklædning, fandt Christian 5.

s) Barfod: Den falsterske Gejstlighed, s. 95.

6) Danmarks Riges Historie, IV, s. 668. 
Zitzscher vardig til det anselige slots-prædicatur i Glückstadt.

Christian 4. havde i 1616 med stor bekostning anlagt byen Glückstadt i det såkaldte »Wildniss«, et marskdistrikt ved Elbens nordlige bred ved østgransen af det kongelige distrikt. Han ville ved at anlægge denne by hindre, at Hamborg, Tønning og Altona tiltog sig al handel på Nordsøen og Elben, og samtidig under den optrækkende konflikt mellem katolske og protestantiske magter sikre sin krigsflåde en havn ved Elben. For at trække indbyggere til byen, gav man visse privilegier, f. eks. blev alle tilflyttere i de første 20 år fritaget for alle afgifter, og samtidig fik medlemmer af fremmede religionssamfund ret til at slå sig ned $i$ byen og indrette sig med egen gudsdyrkelse, så der var både reformerte, katolikker og jøder i byen. Endvidere havde byen en skole med 4 lærere, en af Holstens få højere skoler. Ved byen lå slottet Glücksburğ, hvor Frederik 3.'s og Sophie Amalies bryllup i sin tid havde stået. Her blev Zitzscher altså præst for slotsmenigheden.

I denne menighed fandt han, skriver Egidius, rette Galater, der tog imod ham som en Guds engel. Der blev of te sat en ring på denne Josefs hånd, ofte rakt denne husholder over Guds hemmeligheder »ein herrliches Gratiale«, ofte indfandt sig »eine extraordinaire Reconnoissance« som et pant på hjertelig bevågenhed.

Hans virksomhed skildres da også i strålende farver. $>0$ Glückliches Glückstadt!«, skriver Egidius. Der fik man en præst, der ligesom Abraham i Beersaba (1. Mosb. 21, 33) plantede mange træer på Guds ager, retfærdighedens traeer, planter Gud til ære, der udryddede genstridige og stikkende torne i menigheden, formildede mange trodsige gemytter, rensede mangt et mudret vand, førte mange uenige til Araunas tærskeplads og forsonede dem (2. Sam. 24.). Han forandrede de »fast incorrigible», styrkede de vaklende knæ, der stod usikre som vand, helbredte de bedrøvede sjæle med salven i Gilead, med evangeliets trost.

Disse stærke ord kan suppleres med Flensborg-rektoren, Johs. Mollers, skildring i „Cimbria litterata «. Han fortæller, at Zitzscher blev overordentlig afholdt af sine tilhørere på grund 
af sin lærdom og på grund af sin ualmindelige gejstlige veltalenhed i forbindelse med et lykkeligt udarbejdet, udtryksfuldt foredrag, endvidere på grund af sin hellige vandel, og endelig på grund af den enestående nidkærhed, hvormed han indprentede dem nødvendigheden af en kristen livsførelse. Han satte på sin side så megen pris på deres kærlighed til ham, at skønt han flere gange blev opfordret til at søge mere betydelige kald, så ville han dog ikke forlade denne menighed.

Så vidt den pietetisk indstillede Moller. Man har imidlertid også et tiltalende billede af Zitzscher fra en mand som Morten Reenberg. Skildringen er ganske vist f $\varnothing$ rst nedskrevet af præsten Fr. Monrad, en bekendt af Reenberg, efter dennes død 1736. Men Monrad har åbenbart kendt Reenberg godt, og hans skildring hviler sikkert på Reenbergs egne mundtlige meddelelser. Reenberg må have været ca. 25 år gammel, da han kom til Zitzscher i Glückstadt kort efter dennes ansættelse. Reenberg havde - hedder det - fattet høje tanker om Zitzscher, »den store Theolog ", medens han prædikede på Amalienborg. Reenberg kom nu med et anbefalingsbrev fra sin broder, den senere landsdommer i Jylland, Tøger Reenberg. Monrad gengiver så Reenbergs beretning om sit møde med Zitzscher: $\gg$ Jeg traf ham paa hans Bibliothek og leverede ham Brevet. Da han havde læst det, sagde han smilende til mig: Han er vel lærdere end jeg. Jeg saa mig om, og blev vaer, at der stod en Stok i en Krog; jeg tog samme og leverede ham den med de Ord: »Han maa ligesaa gjerne prygle mig med denne Stok, som han vil sige saadanne Ord til mig «. Indfaldet behagede Zitzscher, som var meget lystig til Sinds. Hos denne brave Mand forblev han i to Aar, laa i hans Hus og studerede der ej alene Theologien, men ogsaa Jus naturæ et gentium. Han fandt her den bedste Lejlighed til at forfremmes i Videnskaberne, siden den Mands daglige Omgang var for ham som et levende Bogskab, og hans anseelige Bibliothek stod ham altid aabent for .... Denne brave Mands Ihukommelse levede hos vor Reenberg, saa længe han levede, i st $\phi$ rste Ereminde og Velsignelse, og ved Anledning deraf sagde han ofte: "Man kan vel tidt lare udenfor Akademiet mere end paa det, siden Lærerne der have for mange at læse for, saa de 
ikke sige deres Mening, og desuden have for meget andet at bestille $\left.\ll .^{\top}\right)$

Reenberg var en af tidens mest djærve og redelige skikkelser, en mand, der for sit sunde judicium er blevet sammenlignet med Holberg, og som senere som stiftsprovst ved Frue Kirke på Christian 6.'s tid var modig nok til at gå hårdt imod pietismen. Det siger et $\mathrm{og}$ andet om Zitzscher, at Reenberg satte ham så højt.

1693 modtog Zitzscher kaldelse til sognepræste- og provsteembedet i Tønder. Han fortæller i sin afskedsprædiken i Glückstadt: Den 9. august 1693 var to fremmede i kirken. De kom bagefter til ham $i$ hans hus som udsendinge fra Tønder for at tilbyde ham embedet som provst og førstepræst. Han henvendte sig da til kongen, der svarede: sagen er fra Gud, man kan ikke være imod den.

De to fremmede har formodentlig været et par medlemmer af rådet $\mathrm{i}$ Tønder. Rådet havde nemlig præsentationsret, som det hed, dvs. det havde ret til at præsentere de kandidater, som så menigheden (dvs. alle, der havde egen arne) traf valget imellem. ${ }^{8}$ ) I rådet sad dengang den af byens historie fortjente borgmester Barth. Hieronymus Schultz,") endvidere den af hertugen på Gottorp - efter rådets forslag - valgte borgmester Jacob Roost, ${ }^{10}$ ) rådmand Lorenz Tychsen, der 1708 viste sin interesse for kirken ved at skænke den en oblatæske,"1) Tychsens svigersøn, købmand Friedr. Langhein, ${ }^{12}$ ) og endelig den pietistisk indstillede kniplingshandler Peter Struck, der skænkede en kapital til oprettelse af vajsenhuset i Tønder. Det er ikke usandsynligt, at den kirkeligt interesserede Struck bar været en af de to udsendinge til Glückstadt.

At Zitzscher henvendte sig til kongen, er naturligt. Han var ansat af kongen i Glückstadt, og yderligere var der nu tale

7) Kirkehist. Saml. 3, III, 486.

8) Ludw. Andresen: Geschichte der Stadt Tondern, 1939, s. 171.

9) Sammesteds s. XI.

10) Tønder gennem Tiderne, 1943, s. 92.

11) Sammesteds s. 582.

12) Ludw. Andresen: Beiträge zur neueren Geschichte der Stadt Tondern, 1943, s. 30. Tønder gennem Tiderne s. 97. 
om, at han skulle overflyttes fra kongeligt til gottorpsk landområde, idet T $\varnothing$ nder stod under Gottorp. Der synes dog ikke at foreligge mindste vidnesbyrd om, at der skulle have varet problemer af national art ved denne sag.

Både $Z$ itzscher og Egidius har meget travlt med at afvise alle ondsindede beskyldninger mod Zitzscher for at have varet ude om det nye embede. I afskedsprædikenen i Glückstadt forsikrer Zitzscher, at han ikke drives af gerrighed eller af lyst til ære, ikke af lyst til ro, men kun af Guds kald. »Ingen skal opdigte et kald, hvor det ikke er, men heller ingen skal modsætte sig kaldet, hvor det virkelig er «. I tiltrædelsespræedikenen i Tonder erklærer han, at da udsendingene kom til ham, tænkte han lige så lidt på dette provsti og dette pastorat, som på en kardinals purpur eller den romerske afguds tredobbelte krone (dvs. pavekronen), han txnkte lige så lidt på denne by, som Peter under sit syn tænkte på Cornelius' hus. Det ville være formasteligt at sige, at han havde haft noget syn, men hvad der beroliger ham lige så meget, som apostlens syn beroligede denne, det var et sammentræf af omstandigheder ved kaldelsen, der måtte gælde som et guddommeligt kald. Hvad han hermed sigter til, vides ikke. Egidius understreger, at hvis hans kaldelse ikke har været guddommelig, så er der ingen, som man med sandhed kan tillægge dette prædikat. Henvendelsen kom ham ganske uventet, så han let kunde føle sig overbevist om, at det var Guds værk. Det må være en rigtig $\gg$ Python«, en rigtig l $\phi$ gnedjævel, som ville sige, at han forud havde udregnet dette embedes indtagter, at han havde vidst, man ville kalde ham, f $\varnothing \mathbf{r}$ det mundtlige forslag kom.

Om hans virksomhed i Tønder skriver Egidius, at han administrerede sine embedsforretninger med glad munterhed. Hvad han gjorde, gjorde han med flyvende hurtighed. Han var en tro Kristi tjener, der flittigt passede det embede, der var ham betroet. Hans liv og hans lare stod »in guter Correspondance «. Han var ydmyg, sagtmodig og tålmodig. Og han var oprigtig. Hvad han sagde, det mente han også. Han var for de fattige en Job, der gerne rakte dem sin hjælpende hånd, idet han kristeligt betænkte, at almisserne på grund af deres nådebelø̋nning i 
himlen var »die Profitirligste Kunst«, som Chrysostomos siger.

Hans tale gik gennem marv og ben. Hvis alle pradikanter var så »religieux som han, er Egidius forvisset om, at ingen ville blive fordømt.

Desværre findes som sagt ikke meget bevaret af hans pratdikener, kun nogle ligprædikener $\mathrm{og}$ brudstykker af andre prædikener. Men et og andet viser de, nok til at karakterisere hans energiske og nidkære forkyndelse.

Han ønsker ikke at spise sine tilhørere af med fabler. Han ved, at nogle bruger dette greb for at lokke folk i kirke og briger ved siden af de fornøjelige inventioner også at føje noget opbyggeligt til. Men han har aldrig truffet den metode anvendt hos profeter, apostle eller hos Kristus.

Man hører undertiden sagt, at den ortodokse tid var en $d \phi d$ tid, hvor interessen for den rene lære kvalte det religiøse liv. Dette indtryk bekræftes ikke, når man læser Zitzschers prædikener. Det personlige religiøse liv er ham mindst lige så vigtigt som lærens renhed. Det har for ham to sider: I ordet taler Gud med os, i bønnen taler vi med Gud.

Bønnen er ham noget meget vasentligt. Om biskop Erdmann beretter han, at det var hans daglige beskæftigelse at bøje knæ. »Er war ein Beter«. Aldrig laste han i bibelen uden at bede om oplysning. Når hans bedrøvelse var størst, var bønnen ham narmest. Bønnen var en mur om hans liv, hvormed han rustede sig mod synden. Og havde han særlige opgaver at løse, anstillede han ikke blot en »extraordinaire Devotion«, men han bad sine fortrolige at forelagge sagen for himlens og jordens dommer.

Personlig tilegnelse er for Zitzscher noget fundamentalt. Den kristne, som ikke er præst, er ikke kristen. Den menighed, i hvilken tilhørerne ikke er præster, bliver kun dårligt opbygget af præsterne. Hvad en præst prædiker fra menighedens prædikestol, det skal hver kristen prædike for sig selv i sit eget hjem. Ved denne prædiken eller hemmelige overvejelser af det, der er prædiket, opbygger hver kristen sig selv til det hellige præstedømme.

For at ordet således kan tilegnes personligt, må lorkyndelsen tilpasses efter tilhørerne. Derfor slår Zitzscher siğ ikke - 
som mange ortodokse præster gjorde det - til ro med at forkynde den rene lære og så overlade det til tilhørerne selv, hvordan de vil modtage forkyndelsen. Han foler det som et ansvar, der påhviler ham, at $\mathbf{\phi} \phi$ rge for at ordet tilpasses efter tilhørernes forudsætninger. De enfoldige må man forklare ABC'en i kristendommen. Med de bedre underviste kan man træde ind $\mathbf{i}$ hemmelighedernes akademi og højskole.

Derfor er det ikke nok for præsten at studere bibelen. Han

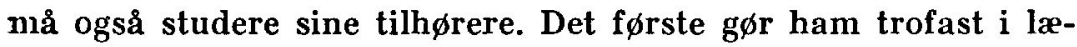
ren, det andet $\mathrm{g} \phi \mathbf{r}$ ham trofast $\mathrm{i}$ anvendelsen, »Applicationen «, af læren. En præst er derfor ikke færdig med at arbejde, fordi han har fået embede. Man tro ikke, at præstekjolen bringer jubelårets privilegium med sig. Nej, så er tiden inde til at svede. Den dobbelte bog: bibelen og det menneskelige hjerte bliver aldrig forklaret så tydeligt på akademier som i skriftestolene. Guds bibel og tilhørernes hjerte kan aldrig blive studeret flittigt nok. Den, som bruger al sin tid dertil, han finder ikke tilnærmelsesvis alt, hvad der skjuler sig i dette dobbelte dyb.

I det hele har Zitzscher stærke ord om præstens forpligtelser. Præsten må bede i sit lønkammer. Ligesom man af frugterne kan se, hvad de store har forhandlet $i$ lønkammeret, således kan man også af frugterne se, hvordan præsterne beder i lønkammeret.

For præstens opgave som sjælesørger har Zitzscher stor forståelse. Prædikanten må både kunne tordne og trøste.

Egidius siger om Zitzscher, at han kunne både straffe og trøste: strøede han en hård straffeprædikens gloende kul over hårde hoveder og forstokkede hjerter, så havde han, som en smelter, en særlig nåde fra Gud til at blødgøre dem. Og hvilken mand var han ikke i skriftestolen! Zitzscher fortæller selv, at han har haft mange anfægtede for sig, der vred deres hænder af fortvivlelse over de onde tanker, der mod deres vilje brusede ind over dem, og som ligesom Paulus mere end tre gange anråbte den højeste om, at Satan måtte vige fra dem. Han har kun altfor ofte erfaret, hvad møje det koster at tale sådanne gode sjæle til ro, at de kan skælne mellem det, der er virket af Satan, og det, der er virket af Gud. 
Som udtryk for den personlige inderlighed $\mathrm{i}$ tilegnelsen taler Zitzscher om sjælen som en bolig for Jesus, som et lille Zion, hvor Guds arne er. Der er hos ham et drag af mystik, der peger tilbage til Bernhard af Clairvaux $i$ middelalderen og frem til pietismen. Han siger om Erdmann, at han var ikke nogen indbildt hellig, og at man i skriftestolen så, at han folte sig som den fortabte $s ø n$, at han for at undfly straffen og nyde nåden krøb som en forskræmt due ind i klippespalten hos sin Jesus. Billedet er hentet fra Bernhards udlægning af højsangen (Zitzscher kendte Saint Thierrys levnedstegning af Bernhard): Kristi sår er det sted, hvor sjælen finder hvile, som duen finder hvile i klipperevnen.

Lidelsen og tårerne har deres plads i Zitzschers forkyndelse: Den kære Gud har således forelsket sig $i$ »die rohte Liverei«, at selv om han har en $s \phi n$ uden synd, så vil han dog ikke have en s $\varnothing$ n $\gg$ ohne Striemen«. De bedste kirker svømmer i blod, de bedste kristne suømmer i tårer. Som Salamanderen (Ildens and $\mathrm{i}$ den gamle alkymi) kan ligge $\mathrm{i}$ ilden uden at blive fortæret, således kan den kristne være på korsvandring uden dog at blive trykket til jorden.

En del polemik er der hos Zitzscher. Katolicismen angriber han, fordi den vil finde døren til himlen $i$ en munkekappe og trøste den døende med hans meriter. Der er dog ingen sa hellig, at hverken Gud eller menneske kan overbevise ham om nogen synd. Calvinismen (»den stoiske kristendom《) bebrejder han, at den vil trøste mennesker med Guds forudbestemmelse. Der er dog ingen, der kan vide, om de hører til dem, som Gud har forudbestemt til frelse.

Et aktuelt problem for Zitzscher var den religiøse ligegyldighed, der åbenbart var et velkendt fænomen i datiden. 1683 skrev Anthon Heimreich i sin slesvigske kirkehistorie om sin samtids ateister, at de står til skamme overfor de gamle nordiske hedninger, der dog ikke var så umenneskelige og ufornuftige, at de fornægtede guddommen og forkastede al gudsdyrkelse. ${ }^{13}$ ) Rent praktisk viste ligegyldigheden sig ved svigtende kirkebes $\phi g$. T $\phi$ -

13) A. Heimreich: Schleswigische Kirchen Historie, 1683, s. 11. 
ders bursprog (vedtægt) 1691 pålagde borgerne flittigt at søge kirken »og ikke at spadsere foran Dørene paa Kirkegaarden og Torvet og ikke sidde i $\emptyset \mathrm{l}$ - og Vinhuse eller Brandevinskroer.$^{14}$ )

Zitzscher var ikke den, der tav stille overfor dette fanomen. Han talte mod »die spöttische Welt», der kaster bibelen under bænken og bliver en spotter sit hele liv. Han mente ikke, verden nogensinde var nået højere i denne helvedes-kunst. Tidligere lød spotten over bibelen fra hedningers mund. Nu berømmes selv blandt kristne mennesker den, der angriber ordet. Men det kan aldrig gå den godt, der holder sig fra Guds forsamling.

Zitzschers embedstid i Tønder blev kun kort. »Wir hatten ihn lieb / Gott hatte ihn noch lieber. Darumb eilete er mit ihm aus diesem bösen Leben«, skriver Egidius. Han d $\phi$ de 1697. Traditionen beretter, at hans læge gav ham en for stark dosis. morfin. Han var da 45 år gammel.

Generationer og tidsaldre har ofte vanskeligt ved at mødes. Ikke mindst er barokken for nutiden en underlig fjern tid. Den taler et fremmed sprog. Det galder også Zitzscher. Der er i hans prædikener megen ordrigdom og - - som i barokkens kunst megen søgt og svulstig kunstfardighed og anmassende lard symbolik.

Men bag dette fremmedartede mærker man et såre bestemt sigte: Ordet skal tilegnes, det skal anvendes i den enkeltes personlige liv. Den kristne bør gentage prastens prædiken overfor sig selv. Betoningen af inderligheden kan få Zitzscher til at. bruge den middelalderlige mystiks sprog. Og i forbindelse med dette personlige i hans forkyndelse står det, at han forstår, at mennesker kan tilegne sig kristendommen på forskellig måde og ikke efter et bestemt skema. Derfor er det, han finder det nødvendigt for en præst ikke blot at studere bibelen, men også at studere det menneskelige hjerte.

Alt dette vidner om, at Zitzschers ortodoksi ikke er noget dødt. Og dog kan han heller ikke karakteriseres som pietist. Han må placeres $i$ den religiøse bevægelse, der danner overgangen fra ortodoksi til pietisme, og som har fundet sit kraf-

14) Tønder gennem Tiderne, 1943, s. 117. 
tigste udtryk i Kingos salmedigtning. Tendensen hos Zitzscher og hos Kingo er i mange henseender den samme. Også Kingo vil berede til »sand Gudfrygtighed«, og også Kingo viser forståelse for, at »den religiøse Udviklings Veje er forskelligartede $\left.\ll .{ }^{15}\right)$

Der kom kort efter Zitzschers død en kraftig pietistisk vækkelse på Tønderegnen. Zitzscher og hans efterf $\varnothing$ lger, Reimarus, har måske deres del af æren for, at denne pietisme fandt en så frugtbar jordbund i Vestslesvig.

15) Se J. Oskar Andersen: Om Kingos Psalmedigtning, Dansk Kirkeliv, 1934 , s. 15 ff. 